Relations industrielles

Industrial Relations

\title{
From Serious Shortage of Researchers to OHS Law Changes and Growing Industrial Needs
}

A Dynamic and Quiet Force

De la pénurie de relève préoccupante aux changements de la LSST et aux besoins industriels grandissants

Une force dynamique et tranquille

\section{Una fuerza dinámica y tranquila}

\section{De la preocupación sobre el relevo generacional a las necesidades crecientes de la industria, pasando por los cambios en la ley de salud y seguridad ocupacional}

\author{
Sylvie Nadeau, Julien Fatisson, Adel Badri et Behnam Emami-Mehrgani
}

Volume 68, numéro 4, automne 2013

Le Réseau de recherche en santé et en sécurité du travail du Québec : un bilan de dix ans

The Quebec Occupational Health and Safety Research Network: A

Ten Year Update

URI : https://id.erudit.org/iderudit/1023007ar

DOI : https://doi.org/10.7202/1023007ar

Aller au sommaire du numéro

Éditeur(s)

Département des relations industrielles de l’Université Laval

ISSN

0034-379X (imprimé)

1703-8138 (numérique)

Découvrir la revue

Citer cet article

Nadeau, S., Fatisson, J., Badri, A. \& Emami-Mehrgani, B. (2013). From Serious Shortage of Researchers to OHS Law Changes and Growing Industrial Needs: A Dynamic and Quiet Force. Relations industrielles / Industrial Relations, 68(4), 608-622. https://doi.org/10.7202/1023007ar

\section{Résumé de l'article}

Les scientifiques ayant soulevés des préoccupations liées aux avancées technologiques et aux risques associés, la communauté scientifique québécoise a mis en place le regroupement stratégique sécurité du travail au sein du Réseau de recherche en santé et en sécurité du travail du Québec (RRSSTQ). Ceci a d'abord favorisé un premier rapprochement géographique des chercheurs facilitant ainsi l'échange et le transfert de connaissances. Grâce à leurs diverses thématiques de recherche, les premiers membres du regroupement ont fait un premier constat de la situation critique en matière de sécurité du travail au niveau industriel. Or, la sécurité du travail est l'affaire de tous et concerne tous les secteurs industriels, tous les milieux et tous les pays. Le regroupement stratégique sécurité du travail a développé ses efforts vers l'internationalisation dans un souci de plus grand déploiement de ses activités. Les créations de regroupements au sein d'autres réseaux mondiaux et d'une revue ont été les premières étapes marquant cette volonté de partage international. Devant le nombre de milieux auxquels la santé et sécurité au travail (SST) s'adresse, les activités de recherche dans le domaine impliquent un regroupement interinstitutionnel et interdisciplinaire. Le regroupement stratégique sécurité du travail du RRSSTQ montre l'exemple en impliquant des chercheurs venant de tous les domaines et de plusieurs universités et institutions de recherche québécoises. Les thématiques de recherche au sein du regroupement stratégique sont toutes aussi variées et complémentaires. Elles s'étendent de l'étude des moyens d'intégration de la sécurité du travail dans la conception à celle de moyens techniques, organisationnels, normatifs, législatifs de prévention, en passant par le développement de nouveaux dispositifs et d'équipements de protection. Un portrait de la constitution du regroupement stratégique sécurité du travail du RRSSTQ et de son évolution depuis sa création jusqu'à l'aube des dix ans du RRSSTQ a été aussi dressé et analysé pour montrer l'évolution croissante du regroupement stratégique sécurité du travail.
Tous droits réservés (C Département des relations industrielles de l’Université Laval, 2013
Ce document est protégé par la loi sur le droit d'auteur. L'utilisation des services d'Érudit (y compris la reproduction) est assujettie à sa politique d'utilisation que vous pouvez consulter en ligne.

https://apropos.erudit.org/fr/usagers/politique-dutilisation/ 


\title{
From Serious Shortage of Researchers to OHS Law Changes and Growing Industrial Needs: A Dynamic and Quiet Force
}

\author{
Sylvie Nadeau, Julien Fatisson, Adel Badri and \\ Behnam Emami-Mehrgani
}

\begin{abstract}
An initial observation by the work safety research community of the Quebec Occupational Health and Safety Research Network (QOHSRN) reveals that occupational safety, an aspect affecting all industrial sectors, requires international exchanges to meet the objectives and expand the knowledge gained within the network. This historical review is also meant to show the diversity of the work safety research community goals and the need to develop intersectoral research projects. The growing and essential involvement of student members within the research community ensures a solid future in that regard.
\end{abstract}

KEYWORDS: occupational safety, industrial research, intersectoriality, international deployment

\section{Introduction}

The integration of occupational health and safety (OHS) in industrial practices aimed at operations and their performance is a major concern among various stakeholders targeting a global risk management approach. Researchers and practitioners are looking to improve work conditions to create a better quality of working life, while increasing the productivity of human and material resources. The spectacular technological development, changes in laws and regulations, market globalization, complexity of production systems and organizational

Sylvie Nadeau, Eng. Ph.D., Professor, Mechanical Engineering Department, École de technologie supérieure, Montréal, Quebec (sylvie.nadeau@etsmtl.ca).

Julien Fatisson, Ph.D., Research Associate, Mechanical Engineering Department, École de technologie supérieure, Montréal, Quebec (julien.fatisson@etsmtl.ca).

Adel Badri, Ph.D., OHS Professional, Sherbrooke, Quebec (badri.adel@gmail.com).

Behnam Emami-Mehrgani, Ph.D., Postdoctoral Student, Department of Mechanical and Industrial Engineering, Ryerson University, Toronto, Ontario (emamimehrgani@gmail.com).

Acknowledgements: The chair of the work safety research community and her assistant would like to thank all component members for their motivation and perseverance in their respective research activities, in regard to occupational safety. They would also like to thank J. Dagenais for proofreading the French version of this paper. 
changes created numerous problems when designing, applying and using work means and methods. Indeed, production systems are increasingly integrated and dynamic. High value-added products must be made on the technical front and in terms of knowledge on high quantity levels and high levels of customization (Claudon, Daille-Lefèvre and Marsot, 2008; Conseil de la science et de la technologie, 2006).

Numerous challenges thus emerged in several industrial sectors to continue ensuring the safety and integrity of workers and users. The researchers' mission then became more complex and now requires systematic consideration of occupational safety risks. To address these challenges, the work safety research community of the Quebec Occupational Health and Safety Research Network (QOHSRN) has been constantly evolving since its creation in 2002. At the beginning, its members proposed various collective and interdisciplinary research projects as part of eight prevention themes. In an effort to promote the implementation of OHS measures, various innovative projects were and are still being implemented to address the issues raised by the development of the industrial world. These projects, whether specific or global and related directly or indirectly to occupational safety, help to improve knowledge on the subject.

The portfolio growth, amount of funding provided, continued growth of its registered affiliates and their diversification, and the distinction of many of its members attest to the quality of the research led and the scientific contribution to the community.

\section{From the Creation to the Observation of the Situation's Criticality}

Need it be recalled that the main industrial goal is currently to produce a maximum of goods, while minimizing the total production cost and respecting the various legal obligations? This goal can only be achieved through efficient and effective production management in which the various resources of a manufacturing system have been optimized. The environment of manufacturing systems thus seems to be constantly evolving and is concerned with accident risks, equipment failures and manufacturing speed variation. Over the last few years, numerous studies looked at the optimization problems affecting manufacturing system production. They took into account their complexity, the competition (cost, quality, delay) and market globalization challenges. Despite these efforts, the frequency and severity of accidents occurring during maintenance interventions remain high in Quebec and in many other countries around the world. This situation highlights the results published by various studies, namely in Quebec (Burlet-Vienney et al., 2009; Burlet-Vienney, 2011; Mutawe, Tsunehara and Glaspey, 2002; AFIM, 2004). 
In 2004, 8\% of accidents compensated in Quebec, or thirteen thousand accidents a year, involved all sorts of dangerous machines (CSST, 2005). Faster technological developments and the arrival of new risks already had the Quebec occupational safety scientific community concerned. In December 2006, the work safety research community, which then was headed by A. D. Ngô (École de technologie supérieure, ÉTS), had 35 members stemming mainly from the natural sciences and engineering fields. Research themes mainly dealt with the analysis of disruption (or exposure) modes and industrial risks, analysis of disruption (or exposure) impacts and risks to human health, industrial risk prevention technology development at the source or, paths and development of interdisciplinary risk management tools (targeting the following themes: quality control, production performance improvement, ergonomics, technological changes, risk perception and risk taking and work dynamics and organization). The risks targeted were mainly: vibrations; protective equipment; tool, machine and industrial process safety; musculoskeletal injuries; air quality and harmful emissions. The industrial applications of these projects also included: dangerous machinery; dangerous industrial processes; electrical work, mining and construction activities.

Despite their national position, researchers were then concerned about the geographical distance that separated them, the specialization of the researchers outside the major urban centers by industrial sector and the shortage of highlyskilled personnel (HSP) and field experts. The introduction of OHS notions in undergraduate training was planned and desired by establishments in charge of preventing work accidents and occupational diseases, people responsible for accrediting engineering training programs and public protection in regard to engineering practice and education (Nadeau et al., 2010). The recruitment of new researchers, whose application fields did not cover OHS at first, was considered a key avenue. A community of practice (COP) in occupational safety and industrial risk control was then created and was able to deliver, as is the case today, some ten conferences a year, thus allowing researchers, practitioners and students to strengthen ties.

\section{From the First Structuring Attempts to Intersectorality}

In 2011, seven workers died in Quebec following a failure linked to occupational safety; 3,552 injuries occurred following interactions with all sorts of dangerous machines including presses, shears, cutting machines, saws, lifts and tractors and 767 injuries were caused by access to a moving equipment part (CSST, 2011). Although the number of deaths seems to be decreasing regarding occupational safety problems, the number of related injuries remains quite high. Activating, powering up and maintaining certain equipment poses major challenges to the metal and electric product and transport, mining, forestry, textile industry, furni- 
ture, pulp and paper, agriculture and construction equipment sectors. There are numerous and diversified occupational safety prevention methods.

The integration and dynamism of production systems and complexity, volume and customization of high value-added products (Conseil de la science et de la technologie, 2006; Claudon, Daille-Lefèvre and Marsot, 2008) then worried the occupational safety scientific community. Simultaneously, the engineering practice has become more complex and systemic risk management (including OHS-related risks) became essential (OECD, 2004). The Ordre des ingénieurs du Québec (OIQ) then planned, and still today, risk management according to a global approach, integrating risks to OHS, operational safety, public safety and environmental protection (OIQ, 2013).

Moreover, in December 2008, the work safety research community had recruited decision support and project management experts to develop integrated operational and OHS risk management tools. Furthermore, in cooperation with the nanotoxicology research community, this research community had recruited numerous thermo-fluidians to study the dispersion of nanoparticles in the workplace air environment and their settlement in lungs and lung alveoli. Such expertise is needed to improve knowledge on the risks posed by nanoparticles. Indeed, the development of flexible, dynamic and integrated tools that help to pool and share the vast range of knowledge on the risks posed by nanoparticles in a reliable and easily usable way becomes imperative and even urgent (Nadeau et al., 2012). Also, in order to ensure worker safety, broader and more comprehensive support, including evolutionary and adaptive risk evaluation tools, is needed to allow for the implementation of proper nanoparticle production control measures. The arrival of new researchers whose application fields did not initially cover OHS led to the gradual fading away of the distinction between occupational diseases and occupational accidents in the description of research projects. The new researchers mainly target occupational injuries. This increased interdisciplinary exchanges and opened up new cooperation opportunities with the Respiratory Health Network and Center for Asthma in the Workplace, among others. Moreover, the QOHSRN's first common strategic funding materialized in regard to the development of an adaptive management tool for the risks posed by synthetic nanoparticles (Nadeau et al., 2012).

It must be noted that the research community's research program is clearly emerging and also concerns the prevention of injuries stemming from the activation, powering up and maintenance of dangerous machinery. Research efforts have become more focused on the development of new design tools integrating occupational safety; the development of new protection devices based on vision technologies and the controls and command system used for satellites; the technical improvement of various personal protective equipment; the development of 
multicriteria approaches for their evaluation and selection; and the development of protective devices, procedures and tools used to plan for the lockout/tagout of equipment.

As a concrete example, a study was conducted by the Institut de Recherche Robert Sauvé en Santé et Sécurité du Travail (IRSST) on fatal work accidents in Quebec between 1999 and 2003 (Giraud et al., 2008) to have a global view of the impact of maintenance on the risks for Quebec workers. This study was conducted using data provided by the Commission de la Santé et de la Sécurité du Travail (CSST) for the years in question. "According to the CSST's annual reports, 1,275 fatal work accidents occurred between 1990 and 2001 (translation of Giraud et al., 2008)." These reports also show that 163 of those victims (Giraud et al., 2008) died during a maintenance activity such as improving the machine, diagnosing a problem, trying out or repairing a machine, locating a breakdown, inspecting, modifying or rebuilding a machine or ensuring the proper functioning of a machine. According to these results, the researchers concluded that maintenance activities represent a significant proportion of fatal work accidents in Quebec (Giraud et al., 2008). A work accident can then be viewed as a disruption, often with consequences that are much more severe than the failure itself. These hazards, when they occur, cause lots of damages, which in turn limit the company in the achievement of its goals and mission. It must be noted that the increase in safety precautions reduces the frequency of accidents but also increases the total production cost. Among the solutions implemented to overcome these difficulties, lockout/tagout is a possible option. Lockout/tagout consists in locking a machine or equipment using a lock and then discharging all energy sources stored (hydraulic, pneumatic, electric, etc.) to avoid the early start-up of the equipment or machine during interventions on the defective devices. In the industry's current context, many managers and workers mistakenly believe that planning and performing lockout/tagout procedures is time consuming. Consequently, this inactive production time is deemed to reduce the company's performance in regard to the manufacturing pace planned. To solve this problem, the innovative mean time to lockout/tagout (MTTLT) concept was developed by a team at the ÉTS (Emami-Mehrgani, Nadeau and Kenné, 2011). This concept consists in taking into account the lockout/tagout time according to the inventory levels for a given manufacturing system to find an optimal production policy for it. By integrating the MTTLT in a passive redundancy system (redundancy is described as passive when abundant elements are only commissioned at the moment of need; this means that only one of various elements is up and running), the system thus becomes less sensitive to shortage and inventory cost fluctuations while constantly meeting demands. This integration in a passive redundancy manufacturing system hence helped to identify an essential time-space to minimize the possibilities of bypassing protective devices or avoiding lockout/tagout procedures. In other 
words, this concept helped to reduce total production costs, including inventory, shortage and maintenance costs, on an endless horizon and increase the safety level of workers. Human error during maintenance and lockout/tagout activities is very important. B. Emami-Mehrgani's et al. recently modeled the MTTLT and human error for a flexible manufacturing system (FMS), using a command theory based on analytical models to open new research avenues that had not yet been explored. The results of this research project will help to advance knowledge, but will especially contribute to reduce the risks of serious work accidents and optimize the production cost.

Integration of OHS risks to operational risks extends to the design and management of flexible manufacturing systems. The design of flexible manufacturing systems (FMSs) has been traditionally based on the minimization of operational costs and time, both for production and setup. To do this, some of the optimization techniques implemented are based on neuronal networks or genetic, ant or operational research algorithms. In a FMS, the supply and disposal of parts is not always automated and requires regular human intervention, be it assisted or not. The research project that is still in progress consists in coupling the OHS risks with the operational risks during the design of a FMS. B. Ateme-Nguema, S. Nadeau and their team are working on implementing a model integrating the analytical aspects of lift load handling in connection with the identification and analysis of the related risks. This operational and OHS risk link, made during the design phase, will allow for the consistent and efficient development of flexible manufacturing systems. A first field study was conducted for the loading/unloading of a FMS in a wood transformation plant (Ateme-Nguema, Nadeau and Arts, 2009; Nadeau et al., 2013). The analytical modeling is in progress, but the results (Nadeau et al., 2013) already seem promising for the integration of OHS right from the design phase of manufacturing systems.

Other approaches, such as lean manufacturing and project management, are also put forward with the main goal being to ensure worker safety. Indeed, lean manufacturing is a manufacturing philosophy based on the elimination of waste and respect for persons. Yet, many studies (Babson, 1993; Landsbergis, 1999; Lewchuk and Robertson, 1996; Parker, 2003) note that in manufacturing systems managed according to this philosophy, a decrease in cycle times and an increase in work volume coupled with greater labour independence may lead to a deterioration of occupational health and safety. The research question can then be posed as follows: Why is the integration of OHS to lean philosophies problematic? Two descriptive studies conducted as in-depth case studies and taken from the urban infrastructure repair industry and manufacturing sector will be carried out by S. Nadeau (ÉTS), J. Arteau (ÉTS) and J. Wakula (TU Darmstadt), and also involve doctoral candidate C. T. Manolache and masters student A. Sakkouhi. 
The main goals of this research program are first to describe the OHS continuous improvement and management activities currently used in two cases of Quebec businesses and one German case. The research will also describe the integration efforts of OHS and continuous improvement activities. Finally, it will propose OHS integration solutions to lean manufacturing and construction. A combination of qualitative and quantitative methods will be used (Manolache et al., 2012; Sakkouhi and Nadeau, 2013).

As previously announced, the goal of project management is to take OHS into account. Indeed, many industrial accidents show the lack of efficiency in the evaluation of these risks and the negligence of various significant factors impacting OHS and the nearby population (Badri, Gbodossou and Nadeau, 2012a). The lack of a global and reliable evaluation, during the project start-up, will generate questionable $\mathrm{OHS}$ and public health decisions and may endanger the organization's sustainability. Although the mining industry uses risk management tools properly, certain large-scale mining projects experienced numerous setbacks because of negligence in taking OHS into account. Despite the level of risk and uncertainty of a mining project and contrary to many other industrial sectors, Badri et al. showed that there are a limited number of researches targeting the management of all risks systematically. This limit can sometimes be explained by the lack of reliable data and absence of expertise contributing to the proper identification and evaluation of all risks (Badri, Gbodossou and Nadeau, 2012a). The goals of the work conducted by these researchers are to propose an OHS risk management approach at various steps, develop identification and analysis tools for OHS risks and their potential consequences and make recommendations regarding the training and support provided to users (practitioners). In this regard, A. Badri's et al. developed a partnership approach model. This model allows for the integration of OHS risks with other types of risks that must be managed by a mining company (organizational, financial, logistics, etc.). This approach results from an action-research involving two Quebec mining companies (Badri, Nadeau and Gbodossou, 2011, 2012b). The work accomplished is based on an in-depth analysis of accident and incident reports, semi-structured interviews, questionnaires and numerous on-site partnership observations. A new danger source concentration concept based on the number and criticality of these sources is proposed with a multicriteria comparison using the Analytic Hierarchy Process (AHP). This concept helps to prioritize the risks, identify the impacts of reinforcement between the sources of danger and thus, choose the best control strategy for well-defined criteria. Based on their field presence, the new approach proposed by A. Badri's et al. helped to quickly prioritize the risks identified and make it possible to further identify possible causes. The OHS databases developed helped evaluators to better manage risks. The researchers emphasize the potential of this new approach aiming to improve work conditions, including 
worker OHS, and anticipate certain potentially serious social, economic and environmental consequences. In the future, interventions may be applied to other Quebec mining companies. This research work showed the potential to improve and gradually generalize the approach proposed and to make it available to all Quebec gold mines (Badri, 2012).

Faced with the apparent scope of the research activities of the component's different members, the work safety research community must be interinstitutional and interdisciplinary, thus pooling engineers, hygienists, toxicologists, doctors, managers, ethicists and kinesiologists from various universities and research institutions.

\section{From Consolidation to Active International Deployment}

Along with the project development, the work safety research community began its international deployment first through the International Congress on International Risk Engineering (2007 ICIRE and 2009 ICIRE), then by launching, in 2009, the sustainability and risk management component of the Human Factors and Sustainable Development Technical Committee of the International Ergonomics Association (IEA) and finally by launching the IJ-IRE (International Journal on Industrial Risk Engineering) peer-review journal. Numerous succession investments were made by the QOHSRN (sometimes jointly with the ÉTS' Research Team in Work Safety [ÉREST]) through awards and scholarships (M. Clément, U. Sherbrooke; V. H. Vu, ÉTS; N. C. Komgrom, ÉTS; M. Mansour, ÉTS; S. Demers, ÉTS; T. Duy Phong, ÉTS; L. Harrabi, ÉTS). These investments were much appreciated by graduates students who became further involved in the life of the network either by helping to organize the conference, congress (B. AtemeNguema, ÉTS; K. Jaafoura, ÉTS; M. Sabapathipillai, ÉTS; I. Desjardins-David, ÉTS; M. Myal, ÉTS; M. Ibiihal, ÉTS; F. M'Hiri, ÉTS) or general assembly (L. Harrabi, ÉTS), ensuring webmaster services (M. Taleb, ÉTS) or representing young Quebec OHS future researchers at the $9^{\text {th }}$ Annual Inter-Regional Human Factors Conference in Buffalo, USA (I. Desjardins-David, ÉTS).

With the QOHSRN's $10^{\text {th }}$ anniversary fast approaching, the work safety research community, managed by S. Nadeau (ÉTS), now has 108 members. This number is constantly increasing and has increased by 192\% (there were 37 members when the research community was first created). The research community was then mainly composed of regular members (49\%) and only a few students (19\%). Now, most occupational safety component members are students (37\% vs. $31 \%$ regular members) (Figure 1). The proportion of associate members increased from $13 \%$ to $21 \%$, and the distribution now includes members from many institutions (20 vs. 3 when the component was launched) (Figure 2). We emphasize the presence of members from outside Quebec (5\%). The same goes for student 
members, and it is interesting to note that nowadays, almost half of student members come from ÉTS, while less than 30\% of students in the research community came from this institution when the component was launched. Furthermore, with the implementation of the graduate program in Occupational Health and Safety Risk Management at ÉTS in January 2013, we expect this proportion of student members from this institution to keep growing.

It is also important to note the scope of the members' activity fields. At the beginning, the research community was mainly limited to a few universities (ÉTS, UQAM and UdeM) and the IRSST. We now also have members from École Polytechnique de Montréal (4), Université du Québec en Abitibi-Témiscamingue (UQAT) (3), McGill (1) and (5) outside Quebec (Figures 1 and 2). This demonstrates the growing interest for OHS in all universities and that the work safety research community can also interest many people, namely outside Quebec.

\section{FIGURE 1}

Distribution of Members by Status in February 2013 (QOHSRN, February 2013)

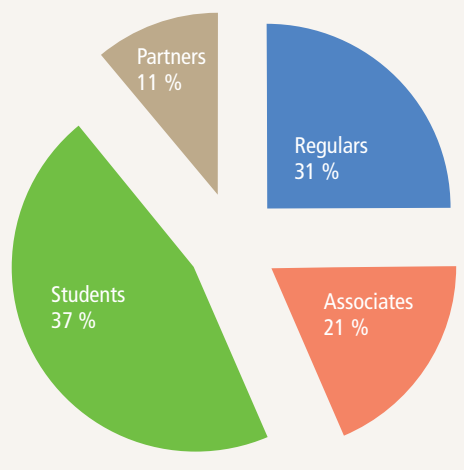

FIGURE 2

Distribution of Members by Institution in February 2013 (QOSHRN, February 2013)

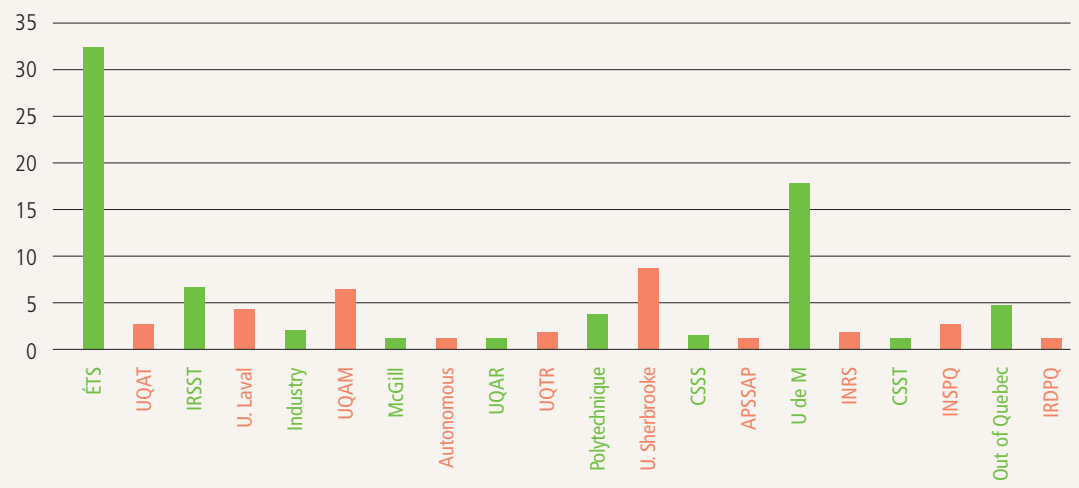


Moreover, the community of practice (CoP) in Occupational Safety and Industrial Risk Management consists of more than 400 practitioners, researchers and students. Researchers develop their collective research around the following prevention methods: 1) elimination of risks at the design stage; 2) risk reduction; 3) installation of isolation, blocking or prohibition devices; 4) personal protection; 5) development and use of work procedures; 6) development of control through air quality engineering; 7) development of control methods through management systems and work organization and 8) knowledge transfer (RRSSTQ, 2012).

The CoP always offers monthly conferences that allow participants to exchange on current themes for the community. The IJ-IRE journal published a special issue stemming from the CARWH-QOHSRN Congress and highlighting the work of I. Desjardins-David and J. Arteau, H. Hadetunji, L. M. M. Pinto, A. Siddique, and S. Samuel, N. Chirane, Y. Frenette, I. Sari-Minodier and M. Gérin. Numerous QOHSRN investments were made on themes related to the management and communication of synthetic nanoparticle risks, industrial project supply decisions, flexible manufacturing system design and management, OHS and continuous improvement integration, environmental and human capital preservation in a context of sustainable development, aircraft wing de-icing/anti-icing, the study of the discal hernia mechanism using the finite-element method, the study of prospective ergonomics constraints of jumbo drills, protective equipment for ultra-deep mines and solvents. In this regard, M. Debia, S. Hallé and R. Tardif obtained funding from the QOHSRN for a project meant to conduct preliminary tests to evaluate the use of solvent activity coefficients to predict the exposure of workers in various exposure models. Each year, workers develop occupational diseases linked to the overexposure to chemicals and namely, to solvents. This topic remains a major concern for occupational health specialists and public health authorities (MSSS, 2003; Lundberg et al., 2005).

Many researchers from the research community are on deployment at the World Health Organization's 2009-2012 Development Plan. Many students received awards and scholarships directly from QOHSRN or through its strategic proposal support program (mainly jointly with ÉREST and ÉTS): M. A. Gaudreau (ÉTS), M. Brummund (ÉTS), S. Demers (ÉTS), B. Emami-Mehrgani (ÉTS), C. T. Manolache (ÉTS), C. Chêne (France), J. Zimolo (France), A. Badri (ÉTS), B. Boudreau-Trudel (ÉTS), G. Viallet (ÉTS), O. Valentin (ÉTS), S. Boyer (ÉTS), R. Bou Serhal (ÉTS), N. Lezzoum (ÉTS), A. Sakkouhi (ÉTS), L. Vinches (ÉTS), M. Ben Salah (ÉTS). Many of these students received awards and scholarships from other organizations such as: ÉTS, APÉTS, FQRNT, IRSST, JASPS, AQHSST, ÉREST, Canadian Acoustics Journal, DSP-Montreal, ASME and Congrégation de Notre-Dame. Many publications were produced internationally: Journal of Production Economics, Safety Science, International Journal of Safety and Security Engineering, Minerals, Annals of 
Occupational Hygiene, Accident Analysis and Prevention in Construction and Engineering, IJ-IRE, at the $2007 \mathrm{CIRI}$ and 2009 CIRI Congress, AQHSST/QOHSRN, AQHSST, IEA (Beijing), Gesellschaft für Arbeitswissenschaft (Germany), American Society of Mechanical Engineers (ASME) as well as the Travail et Santé and as a research notebook (CERGO-ÉNAP and CIRANO).

\section{Closing Remarks and Future Outlook}

The future of occupational safety is just as stimulating. With the modernization of the OHSA, our contribution becomes essential to public health. The Northern Plan, the technological revolution that is underway through nanotechnologies and the massive wave of retirement of field experts in 2013 are once again making issues regarding young researchers a priority. Nevertheless, the QOHSRN's work safety research community is well structured, well networked and resolutely open to interdisciplinarity.

The QOHSRN is positioned to stand out nationally and internationally. It can propose innovative and transferable technological solutions in occupational safety. The research community focuses its collective research on the three following scientific priorities: study on ways to integrate occupational safety at the design stage; development of new protective devices and equipment; study on technical, organizational, normative, and legislative occupational safety prevention methods. We are a dynamic force and well able to meet the growing needs of the Quebec, Canadian and international society.

\section{References}

AFIM (Association française des ingénieurs et responsables de maintenance). 2004. "Santé et sécurité dans l'industrie: les métiers de la maintenance en première ligne." Guide national de la maintenance 2004, 37-66.

Ateme-Nguema, B., S. Nadeau and A. Arts. 2009. "Integration of Health and Safety with Operational Risks: An Overview on Cell Manufacturing." $17^{\text {th }}$ World Congress on Ergonomics, IEA, August $9^{\text {th }}-14^{\text {th }}, 2009$, Beijing, China.

Babson, S. 1993. "Lean or Mean: The MIT Model and Lean Production at Mazda." Labor Studies Journal, 18, 3-24.

Badri, A. 2012. "Pour une meilleure prise en charge de la SST: une nouvelle démarche pratique de gestion des risques de projets miniers." Doctoral thesis. École de technologie supérieure, Montréal.

Badri, A., S. Nadeau and A. Gbodossou. 2011. "Integration of OHS into Risk Management in an Open-Pit Mining Project in Quebec (Canada)." Minerals: Safety \& Health in Mining, 1 (1), 3-29.

Badri, A., A. Gbodossou and S. Nadeau. 2012a. "Occupational Health and Safety Risks: Towards the Integration into Project Management." Safety Science, 50 (2), 190-198. 
Badri, A., S. Nadeau and A. Gbodossou. 2012b. "A Mining Project is a Field of Risks: A Systematic and Preliminary Portrait of Mining Risks." International Journal of Safety \& Security Engineering, 2 (2), 145-166.

Burlet-Vienney, D. 2011. "Développement des connaissances sur la pratique et les spécificités du cadenassage dans le secteur des affaires municipales au Québec." Master's thesis. École Polytechnique de Montréal, Montréal, Canada.

Burlet-Vienney, D., S. Jocelyn, Y. Chinniah, R. Daigle and S. Massé. 2009. Vérification du contenu d'un programme de cadenassage. RF-617 Report. Montréal: IRSST.

Claudon, L., B. Daille-Lefèvre and J. Marsot. 2008. "La révolution du numérique: un atout pour concevoir des postes de travail plus sûrs." Hygiène et sécurité du travail, 210, 5-13.

Conseil de la science et de la technologie. 2006. L'utilisation des technologies de pointe dans le nouveau contexte de la production manufacturière. Québec: Government of Quebec.

CSST. 2005. Rapport annuel d'activité 2004. Quebec: CSST.

CSST. 2011. Rapport annuel de gestion. Quebec: CSST.

Emami-Mehrgani, B., S. Nadeau and J. P. Kenné. 2011. "Lockout/Tagout and Operational Risks in the Production Control of Manufacturing Systems with Passive Redundancy." International Journal of Production Economics, 132, 165-173.

Giraud, L., É. Ledoux, S. Tanchoux and J. J. Pâques. 2008. La maintenance, État de la connaissance et étude exploratoire. R-578 Report. Montréal: IRSST.

Landsbergis, P. 1999. "The Impact of Lean Production and Related New System of Work Organization on Worker Health." Journal of Occupational Health Psychology, 4 (2), 108-130.

Lewchuk, W. and D. Robertson. 1996. "Working Conditions under Lean Production: A WorkerBased Benchmarking Study." Asia Pacific Business Review, 60-81.

Lundberg, I., C. Hogstedt, C. Lidén and G. Nise. 2005. "Organic Solvents and Related Compounds." Textbook of Clinical Occupational and Environmental Medicine. L. Rosenstock, M. R. Cullen, C. A. Brodkin and C. A. Redlich, eds. Philadelphia, PA: Elsevier Saunders, 991-1009.

Manolache, C. T., J. Arteau, S. Nadeau and J. Wakula. 2012. "Lean Construction and OHS in Construction Project Management: The Case of Ironworkers. A Short Review of Literature." Gesellschaft für Arbeitswissenschaft, February $22^{\text {nd }}-24^{\text {th }}, 2012$, Kassel, Germany, 57-61.

MSSS. 2003. Programme national de santé publique 2003-2012. Quebec: Ministère de la santé et des services sociaux, Direction des communications.

Mutawe, A. M., R. Tsunehara and L. A. Glaspey. 2002. "OHSA'S Lockout/Tagout Standards: A Review of Key Requirements." Professional Safety, 47 (2), 20-24.

Nadeau, S., Y. Petit, S. Hallé, F. Morency and L. Dufresne, eds. 2010. Sustainable Development in Mechanical Engineering: Case Studies in Applied Mechanics. New Castle upon Tyne, UK: Cambridge Scholars Publishing.

Nadeau, S., S. Hallé, C. Viau and Y. Cloutier. 2012. "Call for the Development of an Adaptive Tool to Appreciate or Evaluate Risks to Human Health Posed by Synthetic Nanoparticles." International Journal of Safety and Security Engineering, 2 (1), 40-53.

Nadeau, S., B. Ateme-Nguema, C. Chene and J. Zimolo. 2013. "Integration of Occupational Health and Safety into the Design of Flexible Manufacturing Systems: Documented Experience in the Wood-Processing Sector." Gesellschaft für Arbeitswissenschaft, February $27^{\text {th }}$ to March $1^{\text {st }}, 2013$, Krefeld, Germany, 287-290. 
OECD. 2004. Report of the OECD Workshop on Sharing Experience in the Training of Engineers in Risk Management. Paris: OECD.

OIQ (Ordre des ingénieurs du Québec). 2013. Code de déontologie des ingénieurs (c. I-9, r. 6) Loi sur les ingénieurs (L.R.Q., C. I-9) - Code des professions (L.R.Q., C. C-26, a. 87), consulted on January 8, 2013, Quebec, Canada.

Parker, S. 2003 "Longitudinal Effects of Lean Production on Employee Outcomes and the Mediating Role of Work Characteristics." Journal of Applied Psychology, 88 (4), 620-634.

RRSSTQ. 2012. Description of the Occupational Safety Component. Online at: <http://www. rrsstq.com/fra/securite-du-travail.asp>. Website consulted on June 26 ${ }^{\text {th }}, 2012$.

Sakkouhi, A., and S. Nadeau. 2013. "Knowing and Mastering the Impact of Lean Manufacturing on OHS." Gesellschaft für Arbeitswissenschaft, February 27 th to March 15t, 2013, Krefeld, Germany, 521-524.

\section{SUMMARY}

\section{From Serious Shortage of Researchers to OHS Law Changes and Growing Industrial Needs: A Dynamic and Quiet Force}

Scientists having raised concerns about technological advancements and the associated risks, the Quebec scientific community implemented the work safety component within the Quebec Occupational Health and Safety Research Network (QOHSRN). This initially fostered a first geographical connection among scientists, thus facilitating knowledge exchange and transfer. With various research themes, the first component members made an initial observation of the critical situation in regard to occupational safety in the industrial sector. Yet, occupational safety is a shared concern affecting all industrial sectors, environments and countries. The strategic occupational safety component expanded its efforts toward internationalization to increase the visibility of its activities. The creation of components within other global networks and a journal were the first steps marking this desire for international sharing. With the number of environments affected by occupational health and safety (OHS), research activities in this field involve an interinstitutional and interdisciplinary research community. The QOHSRN's strategic occupational safety component leads by example by involving researchers from all fields of study and various Quebec universities and research institutions. Research themes within the component are all equally diverse and complementary. They range from the study of occupational safety integration methods at the design stage to technical, organizational, normative, legislative and preventive methods, and the development of new protection devices and equipment. A portrait of the make-up of the QOHSRN's strategic occupational safety component and its evolution from its creation to the QOHSRN's $10^{\text {th }}$ anniversary was also produced and analyzed to show its growing evolution.

KEYWORDS: occupational safety, industrial research, intersectoriality, international deployment 


\section{RÉSUMÉ}

\section{De la pénurie de relève préoccupante aux changements de la LSST et aux besoins industriels grandissants : une force dynamique et tranquille}

Les scientifiques ayant soulevés des préoccupations liées aux avancées technologiques et aux risques associés, la communauté scientifique québécoise a mis en place le regroupement stratégique sécurité du travail au sein du Réseau de recherche en santé et en sécurité du travail du Québec (RRSSTQ). Ceci a d'abord favorisé un premier rapprochement géographique des chercheurs facilitant ainsi l'échange et le transfert de connaissances. Grâce à leurs diverses thématiques de recherche, les premiers membres du regroupement ont fait un premier constat de la situation critique en matière de sécurité du travail au niveau industriel. Or, la sécurité du travail est l'affaire de tous et concerne tous les secteurs industriels, tous les milieux et tous les pays. Le regroupement stratégique sécurité du travail a développé ses efforts vers l'internationalisation dans un souci de plus grand déploiement de ses activités. Les créations de regroupements au sein d'autres réseaux mondiaux et d'une revue ont été les premières étapes marquant cette volonté de partage international. Devant le nombre de milieux auxquels la santé et sécurité au travail (SST) s'adresse, les activités de recherche dans le domaine impliquent un regroupement interinstitutionnel et interdisciplinaire. Le regroupement stratégique sécurité du travail du RRSSTQ montre l'exemple en impliquant des chercheurs venant de tous les domaines et de plusieurs universités et institutions de recherche québécoises. Les thématiques de recherche au sein du regroupement stratégique sont toutes aussi variées et complémentaires. Elles s'étendent de l'étude des moyens d'intégration de la sécurité du travail dans la conception à celle de moyens techniques, organisationnels, normatifs, législatifs de prévention, en passant par le développement de nouveaux dispositifs et d'équipements de protection. Un portrait de la constitution du regroupement stratégique sécurité du travail du RRSSTQ et de son évolution depuis sa création jusqu'à l'aube des dix ans du RRSSTQ a été aussi dressé et analysé pour montrer l'évolution croissante du regroupement stratégique sécurité du travail.

MOTS-CLÉS : sécurité au travail, recherche industrielle, intersectorialité, déploiement international 


\section{RESUMEN}

\section{Una fuerza dinámica y tranquila: de la preocupación sobre el relevo generacional a las necesidades crecientes de la industria, pasando por los cambios en la ley de salud y seguridad ocupacional}

A la par de los científicos que han resaltado las preocupaciones vinculadas a los progresos tecnológicos y a los riesgos asociados, la comunidad científica quebequense ha implementado un reagrupamiento estratégico sobre la seguridad ocupacional al interior de la Red de investigación en salud y seguridad ocupacional del Quebec (RRSSTQ). Esto ha favorecido un primer acercamiento geográfico de investigadores facilitando así el intercambio y la trasferencia de conocimientos. Gracias a sus diversas temáticas de investigación, los primeros miembros de dicho reagrupamiento han hecho una primera constatación de la situación crítica en materia de seguridad ocupacional a nivel industrial. Sin embargo, la seguridad ocupacional es de interés general y concierne todos los sectores industriales, todos los medios y todos los países. El reagrupamiento estratégico seguridad ocupacional ha desarrollado sus esfuerzos hacia la internacionalización con miras a un despliegue más vasto de sus actividades. La creación de reagrupamientos al interior de otras redes mundiales y de una revista han sido las primeras etapas que han marcado esta voluntad de compartir a nivel internacional. Dado los numerosos medios concernidos por la salud seguridad ocupacional, las actividades de investigación en el campo implican un reagrupamiento interinstitucional e interdisciplinario. El reagrupamiento estratégico seguridad ocupacional del RRSSTQ ilustra esta tendencia implicando investigadores que provienen de todos los campos y de varias universidades e instituciones de investigación quebequenses. Las temáticas de investigación al interior del reagrupamiento estratégico son tanto variadas que complementarias. Estas comprenden desde el estudio de los medios de integración de la seguridad ocupacional en la concepción hasta el estudio de los medios técnicos, organizacionales, normativos, legislativos de prevención, pasando por el desarrollo de nuevos dispositivos y de equipos de protección. Se ha elaborado y analizado también un estado de situación del reagrupamiento estratégico seguridad ocupacional del RRSSTQ desde su creación y su evolución durante los casi diez años de existencia de la RRSSTQ; y ésto, con la intención de mostrar la evolución creciente del reagrupamiento estratégico seguridad ocupacional.

PALABRAS CLAVES: seguridad ocupacional, investigación industrial, inter-sectorial, despliegue internacional 